\title{
Impact of Training on Livelihood of Rural Poultry Farmers
}

\author{
Shashank Kshandakar $^{1 *}$, Nirmal Kumar Singh ${ }^{2}$ and Nishi Nishashree ${ }^{3}$

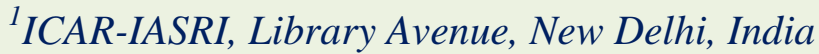 \\ ${ }^{2}$ Block Animal Husbandry officer, Dharhara, Munger, India \\ ${ }^{3} R D \&$ DJ College, Munger, India \\ *Corresponding author
}

\begin{abstract}
A B S T R A C T
Keywords

Backyard poultry

farming, Farm

management, Flock size,

Poultry, Training

Article Info

Accepted:

04 April 2018

Available Online:

10 May 2018

Agriculture and allied sector is the backbone of Indian economy. Agriculture and allied sector not only provides food and nutritional security but also create job opportunity for two-thirds of the population. Among various agriculture and allied farming, Poultry farming is one of the most efficient components of the farmer's economy as it provides eggs, meat, feathers and manures with small capital investment and fewer workforces. India stands $3^{\text {rd }}$ and $5^{\text {th }}$ position in egg and meat production with annual production of 64.45 billion eggs and 2.47 million ton meat respectively. However, the present per-capita availability of eggs and meat is 63 and $2.2 \mathrm{~kg}$ per annum respectively, is lesser than the recommendation of the Nutritional advisory committee, ICMR i.e. 180 eggs and $10.8 \mathrm{~kg}$ poultry meat per annum. To minimize the gap between demand and supply, there is a need of proper training and scientific farming technique (Proper feed supply, Vaccination and better management). The present study aims to evaluate the impact of training on the livelihood of rural poultry farmers under backyard poultry farming.
\end{abstract}

\section{Introduction}

Indian economy is based on agriculture and allied sector, besides providing food and nutritional security agriculture and allied sector also creates employment to the rural people in the shortest possible time.

The agriculture and allied sector contribution in National GDP is about 17.32 percent with annual growth of 4.1 percent (Economic Survey, 2016-17). In agriculture and allied sector, Indian poultry sector is the major game changer with an overall growth of about 7-8\% per annum (0.7\% in National GDP).
At present scenario, the Indian poultry sector has assumed much focus due to the growing demand for poultry products especially in urban areas because of their high food value. Most of the urban and rural population have been nourishing themselves with eggs and meats. Fowls, Ducks and Turkey are the three common Poultry birds, reared either for egg production (i.e. layer birds, 94\% egg production by Fowl, 3\% by Duck and 3\% by other poultry birds) or for meat production (broiler birds). Eggs are very economical source of high-quality protein, vitamins and minerals, while egg yolk contains additional cholesterol, fat-soluble vitamins and essential 
fatty acids. The poultry birds are major source of lean meat with high nutritional value.

The per capita availability of egg was 5 eggs per annum during the period 1950-56. There has been steady increase in per capita availability of egg till 1980s and after 1980s there has been tremendous increase in the per capita availability of egg in last few decades. According to the $19^{\text {th }}$ livestock census (2012), India stands $3^{\text {rd }}$ and $5^{\text {th }}$ position in egg and meat production with annual production of 64.45 billion eggs and 2.47 million ton meat respectively. However, the production is still lesser than the recommendation of the Nutritional advisory committee, ICMR i.e. 180 eggs and $10.8 \mathrm{~kg}$ poultry meat per annum.

Poultry farming is the activity of raising poultry birds with an objective of food security, high productivity, enhanced farm income, effective recycling of resources with minimizing environmental pollution. Types of poultry farming refer to the nature and degree of products or combination of product being produced in a farm and the method of practice used in the farm. Type of farming depends upon various objectives of the farmer, economic and social factors.

Farmer rear indigenous or desi poultry birds (Non-descript) with comparative very low egg and meat production in backyard system or free range system. The farmers are unaware of the farm practices and various challenge related to poultry farming especially when the flock size increases. For making poultry farming economically viable in the rural area, basic training related poultry farming is utmost important. Training changes the level of knowledge and skills of the farmer and provides knowledge regarding identification of improved backyard poultry birds, diseases management, climatic stresses, feed ingredients and poultry waste management. The present study aims to access the impact of training on livelihood of rural poultry farmers.

\section{Materials and Methods}

The domain of the study concentrated on the poultry farmer and the data collected from different blocks of Munger (Bihar). The climate of Munger is subtropical (warm in summer and cold during winter) with a very diverse farming system (www.wikipedia.org). Training related to poultry farming was organised by Regional Poultry Farm, Bhagalpur (Department of animal husbandry), Veterinary officer and NGOs. The training aims to provide some basic knowledge regarding the poultry rearing. The knowledge and interest of farmer are accessed by questionnaire, the questionnaire was divided into five sub-group viz. (1) Housing, Sanitation and waste management (2) Stress Management of Poultry (3) Disease Management and Schedule Vaccination (4) Poultry Nutrition and Feed Formulation and (5) Abnormal Behaviour of Poultry viz. feather pecking, cannibalism, vent pecking and toe pecking.

The training aims to produce educated, skilled and educated workforce. After training, 3-4 weeks old chicks (dual-purpose poultry variety i.e. Vanaraja) are provided by the government under low input poultry production scheme, in this scheme 3-4 weeks old chicks are provided to the farmer at low price (25 chicks @ ₹ 250 for BPL family and @ ₹ 500 for APL family). Vanaraja is a dual purpose variety of poultry birds developed at PD (Reddy et al., 2002). These birds are attractive and multi-colour with high degree of disease resistance. Karuna Sree, et al., 2017 compared the return generated from different chicken varieties and concluded that the overall return generated by Vanaraja was more with respect to Gramapriya and Aseel under extensive system of rearing in tribal and rural areas of West Godavari (A.P.). These birds 
(20-25) can be reared under free-range conditions for egg purpose where ad libitum feed is available. However, in commercial farming, birds can be reared under semiintensive conditions just like commercial broilers. Some of the private hatcheries also supplies chicks (most of them are broilers). Initially, farmers start farming with 100 poultry birds (Chicken) and extend the flock size upto 500.

\section{Source of data}

Data were collected from 50 trained and 50 untrained poultry farmers of Munger (Bihar) during 2013-2016. The data related to training of farmers was obtained from the questionnaire filled by the farmer before and end of the training, whereas production and income data obtained from the farm. For each question, nominal data were collected ( 1 or 0$)$. Code "1" represented the most appropriate answer and code " 0 " for each wrong answer. The averages of all score are summarized in table 1 . The data related to the performance of poultry bird's viz. age and weight at the time of distribution of chicks, age and weight at the $1^{\text {st }}$ egg production are summarized in table 2 .

\section{Statistical analysis}

McNemar's test or McNemar's change test (McNemar, 1947) is a non-parametric test used on paired nominal data. It is applied to $2 \times 2$ contingency tables with a dichotomous trait, with matched pairs of subjects, to determine whether the row and column marginal frequencies are equal. In social science, McNemar's test is most appropriate to study the impact of training or programme.

$\mathrm{H}_{0}$ : There is no impact of training on the Knowledge and skill of the farmer

$\mathrm{H}_{\mathrm{A}}$ : There is impact of training on the Knowledge and skill of the farmer
Under the null hypothesis, with a sufficiently large number of observations, McNemar's test statistic follows the chi-squared distribution with 1 degree of freedom. If the result is significant, null hypothesis is rejected.

\section{Flow chart for statistical analysis in SPSS}

Open Data editor: Start $\rightarrow$ All Programs $\rightarrow$ SPSS for Windows

Choose Analyze from the Menu Bar: Now select Analyze $\rightarrow$ Descriptive Statistics

Descriptive Statistics $\rightarrow$ Frequencies $\rightarrow$ Crosstabs $\rightarrow$ McNemar

Click on Continue to return to the Explore dialog box

Click on OK to get the output.

\section{Results and Discussion}

Improper implementation of programs, illiteracy, poor marketing system, lack of scientific knowledge and farms mechanization are the major constraints to uplift socioeconomic of the farmers. Poultry birds are very sensitive to the adverse climatic condition due to feather body and lack of sweat gland.

The stress over a period of time can deteriorate the production performance and high incidences of stress-related diseases are avoided by providing feed supplement and promoting better housing facilities. Properly ventilated house, clean environment and scientific waste management strategies are the pre-requisite for poultry farming. Poultry house provides protection from harmful animals and the area of house depends upon the flock size. Before keeping the birds inside the poultry house, fumigate the farm or disinfectant with approved chemical with 
great precaution. Wooden and rice bran can be used for making litter and litter should be dry and clean. Poultry feeder drinker and other equipment should be kept at proper place and the number of feeder and drinker depend upon the flock size and area of house. Most of the farmers are unaware and very less number of farmers using scientific management techniques in his/her poultry farm. The impact of training was significant and average knowledge score of the trainees increased from 3.89 to 8.51 (out of 10; Table 1). Similar to present finding Ram et al., 2017 also assess the importance of training and concluded that the farmer needs training. Chatterjee et al., 2015 highlights the importance of farmers training and state that the success on poultry production depends primarily on the locally adapted bird employed, favourable environment and availability of good feed. However, Kabir et al., (2015) also studied the impact of poultry farming on socio-economic condition of Bangladeshi farmer and concluded that the $38 \%$ of the farmer's socioeconomic condition got improved due to family poultry farming.

Table.1 Knowledge level or score of poultry farmer (based on questionnaire)

\begin{tabular}{|c|l|l|l|}
$\begin{array}{r}\text { S. } \\
\text { No. }\end{array}$ & \multicolumn{1}{|c|}{ Farm Management Practices } & \multicolumn{2}{c|}{ Average Score (Out of 10) } \\
\cline { 3 - 4 } & Before Training & After Training \\
\hline $\mathbf{1}$ & Housing, Sanitation and waste management & 6.79 & 9.33 \\
\hline $\mathbf{2}$ & Stress Management of Poultry & 3.05 & 8.21 \\
\hline $\mathbf{3}$ & Disease Management and Schedule Vaccination & 2.72 & 8.18 \\
\hline $\mathbf{4}$ & Poultry Nutrition and Feed Formulation & 4.78 & 8.76 \\
\hline $\mathbf{5}$ & Abnormal Behaviour of Poultry & 2.11 & 8.07 \\
\hline & Overall Average Score & 3.89 & 8.51 \\
\hline
\end{tabular}

Table.2 Descriptive measure regarding the performance of Vanaraja in backyard or free range farming condition

\begin{tabular}{|c|c|c|}
\hline S. No. & Economic traits & Performance \\
\hline 1 & Body weight ( $\mathrm{g}$ ) at the time of distribution i.e. ( $3^{\text {rd }}$ weeks) & $234.3 \pm 22.82 \mathrm{~g}$ \\
\hline 2 & Body weight $(\mathrm{g}),\left(6^{\text {th }}\right.$ weeks $)$ & $528 \pm 39.68 \mathrm{~g}$ \\
\hline 3 & $\begin{array}{l}\text { Body weight ( } \mathrm{g}) \text { at the time of starting of egg production } \\
\text { i.e. }(6 \text { month) }\end{array}$ & $1759 \pm 157.9 \mathrm{~g}$ \\
\hline 4 & Age at $1^{\text {st }}$ egg production (under free range condition) & $172.56 \pm 17.68$ days \\
\hline 5 & $\begin{array}{l}\text { Age at } 11^{\text {st }} \text { egg production (additional feeding of } \\
\text { probiotics, multi-vitamin and minerals mixture) }\end{array}$ & $153.48 \pm 15.23$ days \\
\hline 6 & Average number of egg production/birds & $117.75 \pm 26.21$ \\
\hline
\end{tabular}

There was no significant difference recorded in the weight gain and egg production of poultry birds reared by both trained and untrained farmer but significant different observed in age of first egg production $(\mathrm{p}<0.05)$ under different feeding condition
(Table 2). The average egg production per birds per annum was117.75 \pm 26.21 (upto 70 weeks).

The poultry feed prepared by farmer $(50 \%$ maize; $20-25 \%$ bran; $25-30 \%$ oilseed cake as 
a source of protein along with 5-7\% probiotics, multi-vitamin and minerals mixture) is economical with respect to feed available in market and hence from a flock of 300 birds, farmer makes an additional income of ₹ 5,000-6000 (approx.).

\section{Authors' Contributions}

SK and NKS designed the study. NKS and NN contributed in data collection from the study area. SK conducted the study, analysed the data, drafted and revised the manuscript. All authors read and approved the final manuscript.

\section{Acknowledgments}

The Authors are highly thankful to the Incharge Poultry officer and Gopal Mitra, Munger (Bihar) for providing the necessary support during data collection for the execution of this study.

\section{Competing Interests}

The authors declare that they have no competing interests.

\section{References}

Chatterjee, R.N. and Rajkumar, U. 2015.An overview of poultry production in India. Indian Journal of Animal Health., 54(2): 89-108.

Economic Survey 2016-17. MOF. Government of India (www.indiabudget.gov.in)

\section{How to cite this article:}

Shashank Kshandakar, Nirmal Kumar Singh and Nishi Nishashree. 2018. Impact of Training on Livelihood of Rural Poultry Farmers. Int.J.Curr.Microbiol.App.Sci. 7(05): 241-245. doi: https://doi.org/10.20546/ijcmas.2018.705.031
Kabir, M. S., Asaduzzaman. M. and Dev D. S. 2015. Livelihood improvement through family poultry farming in Mymensingh district. Journal of the Bangladesh Agricultural University, 13(2):247-256.

Karuna Sree, E., T. Vijaya Nirmala, and R. V. S. K. Reddy. 2017. Comparative performance of different varieties of chicken under backyard system of rearing in tribal and rural areas of West Godavari district, A.P. International Journal of Science, Environment and Technology, 2 (6): 1100 - 1104.

Livestock Census. 2012. Department of Animal Husbandry, Dairying and Fisheries. Ministry of Agriculture, Govt. of India.

McNemar, Q. 1947. Note on the sampling error of the difference between correlated proportions or percentages. Psychometrika, 12 (2):153-157.

Ram, D., Singh, M.K. and Laishram, J.M. 2017. Training Needs Assessment of Poultry Farmers in Imphal West and Imphal East of Manipur. International Journal of Current Microbiology and Applied Sciences, 6(9): 2218-2227.

Reddy, M.R., Rao, G.N., Sharma, R.P., Reddy, B.L.N., Gupta, B.R. and Satyanarayana, A. 2002.Genetic study on juvenile traits of Vanaraja chickens. Indian Journal of Animal Sciences, 74 (12): 1229-1231.

www.wikipedia.org 